\title{
THE SCALE FOR THE ATTITUDES OF CUSTOMERS TOWARDS PURCHASING TENDENCY WITHIN THE CONTEXT OF BUSINESS, MARKETING AND SALES OFFICERS' GENDERS: A VALIDITY AND RELIABILITY STUDY
}

Ruhan İRI ${ }^{1}$

\author{
Received Date (Başvuru Tarihi): \\ Accepted Date (Kabul Tarihi): \\ Published Date (Yayın Tarihi):
}

$29 / 05 / 2020$

$27 / 07 / 2020$

$25 / 09 / 2020$

ABSTRACT

Keywords:

Business,

Marketing,

Validity and Reliability Ni⿱ğde

JEL Codes:

M30, M31
The purpose of the study is to develop a scale that will allow measuring the attitudes of customers towards purchasing tendency within the context of the business, marketing and sales officers' genders. Items were developed by the related literature, and content validity was determined through the opinions of 28 field experts. The participants of the study consist of 511 consumers who shopped at corporate or brand business stores that were selected through judgemental sampling method in the city centre of Niğde between 01-31 December 2019. As a result of the exploratory factor analysis conducted to ensure the construct validity of the scale, a four-factor structure consisting of 16 items was obtained. Cronbach alpha reliability coefficient for the whole scale was found as .894. Confirmatory factor analysis results, which were carried out to understand whether this structure fitted the sample data, showed that the fit index of the scale was at an acceptable level. Based on the findings of the study, it can be stated that the scale is valid and reliable, and that it can be used to analyse customers' attitudes towards purchasing tendency within the context of the genders of business, marketing and salespeople in corporate business (brand) stores.

\footnotetext{
${ }^{1}$ Assist. Prof. Dr., Niğde Ömer Halisdemir Unıversıty, Niğde Vocational School of Social Sciences, Department of Marketing and Advertising, ruhaniri@ohu.edu.tr, https://orcid.org/0000-0002-5981-9673
} 


\section{İŞLETME PAZARLAMA VE SATIŞ GÖREVLILLERININ CINSIYYETLERINIIN MÜŞTERILERINN SATIN ALMA EĞİLIMINNE YÖNELIKK TUTUM ÖLÇEĞİ: GEÇERLİK VE GÜVENIRLIKK ÇALIŞMASI}

$\ddot{O Z Z}$

\author{
Anahtar Kelimeler: \\ İşletme, \\ Pazarlama,
}

Geçerlik ve Güvenirlik,

Niğde

\section{JEL Kodlari:}

M30, M31
Çalışma, kurumsal işletme (marka) mağazalarındaki pazarlama ve satış görevlilerinin cinsiyetlerinin müşterilerin satın alma eğilimine yönelik algiların geçerli ve güvenilir olarak ölçmeye olanak tanıyacak bir ölçme aracının geliştirilmesi amacıyla hazırlanmıştır. İlgili literatürden elde edilen bilgiler doğrultusunda maddeler oluşturularak kapsam geçerliğini tespit etmek amactyla 28 uzmandan görüş alınmıştır. Kurumsal işletme mağazalarındaki pazarlama ve satış görevlilerinin cinsiyetlerinin müşterilerin satın alma eğilimine yönelik tutum ölçeği, 01-31 Aralı 2019 tarihleri arasında, çalışmanın örneklemini oluşturan Niğde şehri merkezinde, yargısal olarak seçilen ve kurumsal işletme veya marka işletme mağazalarmdan alışveriş yapan toplam 511 tüketiciyle gerçekleştirilmiştir. Ölçeğin yapı geçerliğini sağlamak amacıyla yapılan açımlayıcı faktör analizi sonucunda 16 maddeden oluşan dört faktörlü bir yapı elde edilmiştir. Cronbach alfa güvenilirlik katsayısı ölçeğin tamamı için, .894 olarak bulunmuştur. Elde edilen bu yapının örneklem verisine iyi uyum gösterip göstermediğini anlamak amacıyla yürütülen doğrulayıcı faktör analizi sonuçlar ise, ölçeğin uygulandığı örnekleme uyumunun kabul edilebilir düzeyde olduğunu göstermiştir. Analiz sonucunda ortaya çıkan bulgulara dayanarak, kurumsal işletme (marka) mağazalarındaki pazarlama ve satış görevlilerinin cinsiyetlerinin müşterilerin satın alma eğilimine yönelik tutum ölçeğinin geçerli ve güvenilir ölçümler üreten bir ölçme aracı olduğu ve işletme mağazalarında pazarlama ve satış görevlisi olarak çalışanların cinsiyetlerinin müşterilerin satın alma eğilimine yönelik algıların ölçmek amacıyla kullanilabileceği söylenebilir. 


\section{INTRODUCTION}

Consumers may differ by gender in their purchasing behaviours, and the gender factor may play an essential role in consumer purchasing decision or product and brand selection (Peterson, 2005: 349). The gender and social gender identity of the individual is an essential factor that determines and shapes the marketing and sales strategies of businesses as well as being useful on the consumers' purchasing phase (Tekvar, 2016: 1603). Also, that the business marketing and salesperson, and the customer are of the same or different gender during the purchase phase can be both important for the communication, harmony and agreement between the customer and seller and influential on the tendency of the customers to purchase.

Although businesses have been carrying out their marketing and sales-related activities via e-commerce over the internet with the widespread use of internet in recent years, mostly corporate or branded businesses, do not cease to perform retail activities in their showrooms or stores. The marketing activities carried out in the stores of the branded companies can be influential on the purchasing decisions of the customers depending on the characteristics of the products and the genders of the marketing assistants and salespeople. The possibility that the gender of the marketing assistants or salespeople, who direct or influence the purchasing decisions of consumers who have the desire to do shopping in the store, maybe important reveals the necessity to research in this regard. In this sense, the sameness or the difference between the genders of the customers and the marketing assistants or salespeople continues to be a critical issue for the attitudes of customers towards purchasing tendency within the framework of business and marketing. Considering that there are few studies in the literature on the customers' purchasing tendencies within the context of the genders of the business marketing assistants and salespeople, this study is considered significant.

\section{THE IMPORTANCE OF GENDER OF BUSINESS MARKETING AND} SALES STAFF IN THE PURCHASING TENDENCY OF CUSTOMERS

The concept of gender is used to explain the biological, genetic characteristics of the individual in society (Ersoy, 2009: 211). Gender has become effective in 
consumption trends, and customers have turned to gender-appropriate products and brands to show their sexual identity (Avery, 2012: 3). Besides being a market segmentation variable in the field of marketing, gender is also a factor in the differentiation of consumer behaviour and its effect on the characteristics, attitudes and behaviours of consumers is examined in most of the research in the marketing literature (Çabuk \& Arac1, 2013: 27). Gender affects customer behaviours associated with gender roles and gender-specific behaviours within a specific society, time and cultural accumulation (resources, values, beliefs, norms, traditional behavioural patterns) in consumer behaviour (Arnould, Price, \& Zinkhan, 2002: 511). The genders of the customers are known to affect their consumption trends and purchasing behaviours. Similarly, it is claimed that the genders of the marketing and sales staff working in the business (brand) stores may also have an impact on the perceptions of the customers towards purchasing tendency.

Consumers' social status is related to the products they use, and their consumption trends vary according to gender. The gender identity obtained through birth is shaped through consumption, and the power individuals gain through their positions and status in society can be closely related to social gender and consumption trends (Karahan \& Adak, 2019: 122).

\section{LITERATURE REVIEW}

In literature, there are several studies on business marketing and sales staff's roles in customers' purchasing tendencies. However, no study exists that examines the effect of the marketing and sales staff's gender on the customers' purchasing tendencies, which is thought to be an essential and exciting issue to be studied by researchers. When the researches on the effects of marketing and salespeople on the purchasing tendency of the customers are examined in the literature, the effect of the sexes of the consumers on the purchasing tendency comes to the fore.

One of the criteria commonly used in the literature on the factors affecting consumer behaviour is gender (K1lıçer, Boyraz \& Tüzemen, 2016: 131). Gender causes differences in consumers' abilities, attitudes, priorities and preferences unique to their genders, and these differences are of great importance in marketing (Barletta, 2003: 16- 
17). Fischer and Arnold (1990) stated that gender is significant on consumers' Christmas shopping (Fischer \& Arnold, 1990: 342). Ndubisi (2006) investigated the role of gender between customer loyalty and the foundations of relational marketing such as trust, communication, loyalty and conflicts, and revealed that consumer gender plays a vital moderate role in customer loyalty. Bakshi (2012) stated that gender behaviours are opposite at every stage of the consumer purchasing decision and that marketers should catch this difference in the best way to gain competitive advantage (Bakshi, 2012: 7). Karahan (2018) examined the gender of shopping in a consumerist society and revealed that both women and men tend to have an intense consumption trend, but the products purchased differ according to gender (Karahan, 2018: 195). Arnold and Bianchi (2001) proposed relational marketing strategies be directed towards customers based on their likelihood of being relational and stated that their being relational would depend on their biological sex as well as their cultural orientation. Akdoğan and Karaarslan (2010), who examined the effect of the people who influence consumers' decisions within business stores with the scenario method, found that salespeople can direct the consumers. Those female students respond more positively to the salespeople than the male students. Lieven (2016) stated that a customer's first encounter with the salesperson is significant in retailing and can quickly help in choosing free tips such as physical, duty or social attraction. It is also asserted that the gender of the salesperson is vital in communicating with the customer as well (Lieven, 2016: 114-115).

\section{PURPOSE OF THE RESEARCH}

The research is prepared with the aim of developing a valid and reliable scale that will allow examining the perceptions of customers towards purchasing tendency within the context of business, marketing and sales officers' genders.

\section{METHOD}

\subsection{The Universe and Sample of the Research}

The exploratory factor and confirmatory factor analysis and reliability studies conducted in the study were carried out with the data obtained from face-to-face questionnaires conducted with 511 consumers who were selected through 
judgemental sampling method from the corporate (brand) business stores in the city centre of Niğde. The study group of the research consists of 511 people who shopped from ten national and international brand stores. It is assumed that a sampling of this size will adequately represent the existing population by $95 \%$ confidence interval. In the research carried out between 01-31 December 2019, a two-stage sampling method was applied. In the first stage, considering the sample size per brand business store, a sample quota (consisting of 50 pieces) was determined. In the second stage, while research groups were created in each brand business store (regardless of a particular day of the week or a particular time of the day), survey forms were applied face-toface to consumers selected by the judgmental sampling method.

\subsection{Model of the Research}

The research was designed in a survey method, which covers the surveys conducted on the whole universe or a group or sampling to make a general judgment about the universe (Karasar, 2019: 72). In this method, qualitative data related to the research problem are first collected and evaluated. Then, quantitative data are created, analysed and interpreted according to the qualitative data obtained. Although this method provides advantages to researchers in many aspects, it is stated that its use in scale development studies will also yield significant results (Creswell, 2014: 56). Accordingly, first of all, the attitude items were created by conducting interviews with a business marketing and sales managers and employees through qualitative methods and literature review. Then, the related tests were applied to the academicians who are experts in the field of business and marketing and the attitude scale for the genders of the marketing and sales staff towards the customers' purchasing tendencies in the business stores was developed.

\subsection{Process Steps of the Study}

The research aims to develop a valid and reliable scale that will allow examining the perceptions of customers towards purchasing tendency within the context of business, marketing and sales officers' genders. The scale was checked by 4 business field experts and 1 marketing specialist in order to ensure content and face validity and necessary corrections were made accordingly. 
After the explanatory factor analysis, confirmatory factor analysis was also made to ensure the construct validity of the scale. Exploratory factor analysis is one of the widely used statistical techniques that combine a large number of interrelated variables within few, influential and independent factors. On the other hand, confirmatory factor analysis is a statistical method used to determine whether variable groups in the determining factors are adequately represented by these factors (Büyüköztürk, 2019; Tabachnick \& Fidell, 2007). The research was carried out on the same data set to support the structure determined by confirmatory factor analysis and exploratory factor analysis. After these analyses, the scale was finalised by interpreting the data. The process steps of the research process are summarised in Table 1.

Table 1. Research Process Steps

\begin{tabular}{lc}
\hline & RESEARCH PROCESS STEPS \\
\hline Creating an Item Pool & $\checkmark$ Meeting with 5 Corporate(Brand) Business Managers \\
& $\checkmark$ Literature review \\
Ensuring Content & $\checkmark$ 22-item item pool \\
Validity & $\checkmark$ Earketing Specialist 28 Instructors \\
Ensuring Structure & $\checkmark$ Confirmatory Factor Analysis \\
Validity & $\checkmark$ Cronbach Alpha Reliability Coefficient \\
Reliability Test & $\checkmark$ Scale with 4 factors and 16 items \\
Final Version of the Scale & $\checkmark$ Source: Made By Author
\end{tabular}

\subsection{Item Development}

In the development process of the scientific research self-efficacy scale, the following processes were carried out in the following order: (1) Literature review and creating an item pool, (2) Expert opinion, (3) Item-total correlations, (4) Item discrimination feature, (5) Exploratory factor analysis, (6) Cronbach Alpha internal consistency reliability, (7) First level confirmatory factor analysis. The research conducted to develop an attitude scale examining the perceptions of customers towards purchasing tendency within the context of business, marketing and sales officers' genders were designed and carried out by this plan.

While creating the scale items, firstly, the related literature was reviewed by the researcher, the studies on the attitudes of the business marketing and sales staff towards the purchasing tendency of the customers were examined, and a pool of items 
was created. Then, a questionnaire with a total of 22 items was created with the marketing and sales managers who had 5-10 years of working experience in brand business stores. This 22-item questionnaire was organised as a scale form for preapplication in line with the opinions and recommendations of 4 academicians who are experts in marketing and sales. The scale form prepared was prepared in the form of 3-Likert type rating from "required" (1) to "unnecessary" (3). This Likert-type rating form was evaluated by 28 academicians who are experts in the field of business and marketing, and the forms analysed in the SPPS program were finalised without removing any of the 22 items.

\subsection{Data Analysis}

Firstly, the scale was analysed in terms of content validity. Exploratory and confirmatory factor analyses were done for the construct validity of the scale. While the factors were found based on the relations between the variables with the exploratory factor analysis, the relationship between the variables was tested with the confirmatory factor analysis (Büyüköztürk, 2010: 123).

\section{FINDINGS}

\subsection{Findings Related to the Content Validity of the Scale}

In order for a scale item to measure the desired property and to obtain objective results, the content validity of the scale must be analysed. Content validity ratios are used in cases where practical applications are not possible in scale development studies. Content validity rates are a preferred method to be used to convert qualitative studies based on expert opinions into quantitative statistical studies (Yurdugül, 2005: 1). Content validity rates were developed by Lawshe (1975; Akt. Yurdugül, 2005: 2), whose approach consists of 6 stages:

$\checkmark$ Establishing a group of fields experts' group,

$\checkmark$ Preparing candidate scale forms,

$\checkmark$ Obtaining expert opinions,

$\checkmark$ Obtaining the content validity ratios of the items,

$\checkmark$ Obtaining the content validity indexes of the scale,

$\checkmark$ Developing the final questionnaire according to the content validity rates/index criteria. 
At least 5 and at most 40 expert opinions are required in Lawshe Technique. Expert opinions on each item are formed as "item measures the targeted structure", "item is related to the structure but unnecessary" or "item does not measure the targeted structure" (Yurdugül, 2005: 2). Accordingly, the Content validity rates are obtained by gathering the opinions of the experts on any item, and the Content validity rates (KGO) are obtained by 1 minus the ratio of the number of experts indicating the "Necessary" view for any item to the total number of experts expressing the opinion about the item.

\section{Formula:}

$\mathrm{KGO}=\underline{\mathbf{N}_{\mathrm{G}}} \_\mathbf{1}$

$\frac{N}{2}$

KGO = Content Validity Rate,

NG = Number of experts who found the item necessary,

$\mathbf{N}=$ It is the total number of experts who expressed an opinion about the item.

The Content Validity Index (Yurdugül, 2005: 3) is shown in Table 2.

Table 2. Values Related to Content Validity

\begin{tabular}{ccc}
\hline Number of Participants & $\stackrel{P<0.05}{\longrightarrow}$ & Minimum Value \\
5 & $\longrightarrow$ & 0,99 \\
6 & $\longrightarrow$ & 0,99 \\
7 & $\longrightarrow$ & 0,99 \\
8 & $\longrightarrow$ & 0,78 \\
9 & $\longrightarrow$ & 0,75 \\
10 & $\longrightarrow$ & 0,62 \\
11 & $\longrightarrow$ & 0,59 \\
12 & $\longrightarrow$ & 0,56 \\
13 & $\longrightarrow$ & 0,54 \\
14 & $\longrightarrow$ & 0,51 \\
15 & $\longrightarrow$ & 0,49 \\
20 & $\longrightarrow$ & 0,42 \\
25 & $\longrightarrow$ & 0,37 \\
30 & $\longrightarrow$ & 0,33 \\
35 & $\longrightarrow$ & 0,31 \\
$40+$ & $\longrightarrow$ & 0,29 \\
\hline
\end{tabular}

Source: Made by the author based on Yurdugül, 2005

Candidate scale forms were created with a group of experts. In this context, the content validity rates (CVR) of 22 items examined by 28 academicians who are experts in business and marketing are given in Table 3. 
Table 3. CVR Values Regarding the Opinions of the Experts on the Content Validity

\begin{tabular}{cccc}
\hline Item No & $\mathbf{N}_{\mathbf{G}}$ & $\mathbf{N}$ & KGO \\
\hline $\mathbf{1}$ & 21 & 28 & 0,43 \\
$\mathbf{2}$ & 21 & 28 & 0,429 \\
$\mathbf{3}$ & 22 & 28 & 0,643 \\
$\mathbf{4}$ & 22 & 28 & 0,643 \\
$\mathbf{5}$ & 20 & 28 & 0,500 \\
$\mathbf{6}$ & 22 & 28 & 0,500 \\
$\mathbf{7}$ & 22 & 28 & 0,571 \\
$\mathbf{8}$ & 18 & 28 & 0,571 \\
$\mathbf{9}$ & 20 & 28 & 0,643 \\
$\mathbf{1 0}$ & 21 & 28 & 0,643 \\
$\mathbf{1 1}$ & 21 & 28 & $-0,214$ \\
$\mathbf{1 2}$ & 19 & 28 & $-0,214$ \\
$\mathbf{1 3}$ & 21 & 28 & 0,357 \\
$\mathbf{1 4}$ & 20 & 28 & 0,357 \\
$\mathbf{1 5}$ & 21 & 28 & 0,571 \\
$\mathbf{1 6}$ & 20 & 28 & 0,571 \\
$\mathbf{1 7}$ & 23 & 28 & 0,714 \\
$\mathbf{1 8}$ & 20 & 28 & 0,714 \\
$\mathbf{1 9}$ & 20 & 28 & 0,429 \\
$\mathbf{2 0}$ & 20 & 28 & 0,429 \\
$\mathbf{2 1}$ & 20 & 28 & 0,43 \\
$\mathbf{2 2}$ & 20 & 28 & 0,43 \\
\hline
\end{tabular}

Source: Made by the author based on Yurdugül, 2005.

The scale items were given to 28 academicians who were experts in the field, and they were subjected to content validity analysis by the Lawshe technique. According to the data obtained from the experts, it was concluded that all the items have content validity.

\subsection{Findings Related to Exploratory Factor Analysis of the Scale}

In this section, findings regarding the validity and reliability of the Scale for the Attitudes of Customers towards Purchasing Tendency within the context of Business, Marketing and Sales Officers' Genders are included. First, it was tested whether the data set is suitable for multivariate statistics. For this, missing data, inverse items, extreme data, normality of the data set, relationships between the items, sample size and sample suitability (KMO and Bartlett's sphericity test) were taken into consideration (Büyüköztürk, 2010; Field, 2009; Tabachnick \& Fidell, 2007). Accordingly, the KMO sample conformity coefficient is .851 (> .60) and Barlett Sphericity test is (indicator of multivariate normal distribution) $\chi^{2}=4415.228(p<.001)$. 
These findings show that the data obtained from the research group are suitable for factor analysis. Kolmogorov Smirnov test ( $p>$.05), histogram graphics, mode, median, arithmetic mean values, and skewness kurtosis coefficients (+2 and -2) were taken into account in the normality tests of the data set (Field, 2009; Kalayc1, 2010).

Table 4. Exploratory (Rotated Main Components) Factor Analysis Results Related to the Scale for the Attitudes of Customers towards Purchasing Tendency within the context of Business, Marketing and Sales Officers' Genders

\begin{tabular}{|c|c|c|c|c|c|c|c|c|}
\hline \multirow{2}{*}{$\begin{array}{c}\text { Item } \\
\text { No }\end{array}$} & \multirow{2}{*}{$\begin{array}{l}\text { Factor } \\
\text { Common } \\
\text { Variance }\end{array}$} & \multirow{2}{*}{$\begin{array}{l}\text { Factor-1 } \\
\text { Load } \\
\text { Value }\end{array}$} & \multicolumn{4}{|c|}{$\begin{array}{c}\text { Factor Load Value After } \\
\text { Rotation }\end{array}$} & \multirow{2}{*}{$\begin{array}{l}\text { Corrected } \\
\text { Item-Total } \\
\text { Correlation }\end{array}$} & \multirow{2}{*}{$\begin{array}{c}\text { Cronbach } \\
\text { Alpha } \\
\text { Level }\end{array}$} \\
\hline & & & F1 & F2 & F3 & F4 & & \\
\hline M4 & ,634 & 693 & ,717 & & & & 690 & \\
\hline M6 & 723 & 749 & 800 & & & & ,741 & \\
\hline M8 & 679, & 754, & & & & & 744 & \\
\hline M10 & 639, & 663, & 780, & & & & 697, & .897 \\
\hline M16 & 553, & 674, & & & & & 655, & \\
\hline M18 & ,564 & 639, & 716 & & & & 648, & \\
\hline M22 & 643, & 704, & 767, & & & & 717, & \\
\hline M3 & 669, & 636, & & 61 & & & 617, & \\
\hline M5 & 777, & 628, & & 83 & & & 670, & 848 \\
\hline M7 & 791 & 663, & & & & & 767, & .848 \\
\hline M9 & 689, & 622, & & 76 & & & 705, & \\
\hline M11 & 551, & 477 & & & 6 & & 440, & \\
\hline M13 & 712 & ,580 & & & 73 & & 620 & .716 \\
\hline M19 & 704, & ,442 & & & 8 & & ,554, & \\
\hline M1 & 812, & ,527 & & & & ,840 & .541 & \\
\hline M2 & 718 & ,553 & & & & 741 & .541 & 699 \\
\hline
\end{tabular}

The Cronbach's Alpha coefficient for the whole scale was found to be .894 .

Source: Made by Author

4 factors were obtained as an evaluation result of the exploratory factor analysis for the Scale for the Attitudes of Customers towards Purchasing Tendency within the context of Business, Marketing and Sales Officers' Genders. The factors explain $27.19 \%, 17.28 \%, 12.23 \%$ and $11.15 \%$ of the total variance related to the scale. The total factor dimensions of the scale explain $67.85 \%$ of the scale. Büyüköztürk (2019) states that a scale can be qualified as sufficient when the variance explained in single-factor scales is $30 \%$ or more (Büyüköztürk, 2019:119). The data obtained as a result of the factor analysis indicate that the validity of the scale is high. 
While the scale consisted of 22 items in the first place, 6 items that were not included in any factor or had a load value below .40 (items 12, 14, 15, 17, 20 and 21) were removed from the scale, the scale decreased to 16 items, and the remaining 16 items were used in the analyses. Having factor common variances of the items close to 1 or above .66 is considered a right solution, but it is stated this is difficult in practice (Büyüköztürk (2019: 119). After factor rotation, the four factors, which consist of 7 items $(4,6,8,10,16,18,22), 4$ items $(3,5,7,9), 3$ items $(11,13,19)$ and the 2 items $(1,2)$ respectively, are named as "customer satisfaction factor according to the marketer or seller gender", "image and attraction factor according to the marketer or seller gender", "communication factor according to the marketer or seller gender" and "recommendation factor according to the marketer or seller gender" respectively. Cronbach Alfa reliability analysis was carried out in order to determine the reliability of the scale. According to the statistics, Cronbach Alpha value was found as .894 in the whole scale. Cronbach Alpha values for the four factors of the scale was found .897, .848, .716 and.699 respectively. Özdamar (2020:673) states that a reliability coefficient that can be considered sufficient in a Likert-ty pe rating should be as close to 1 as possible. According to the results of the results mentioned above, it can be asserted that the reliability of the attitude scale towards the purchasing tendency of the genders of business marketing and salespeople is high. 


\subsection{Confirmatory Factor Analysis Concerning the Scale Findings}

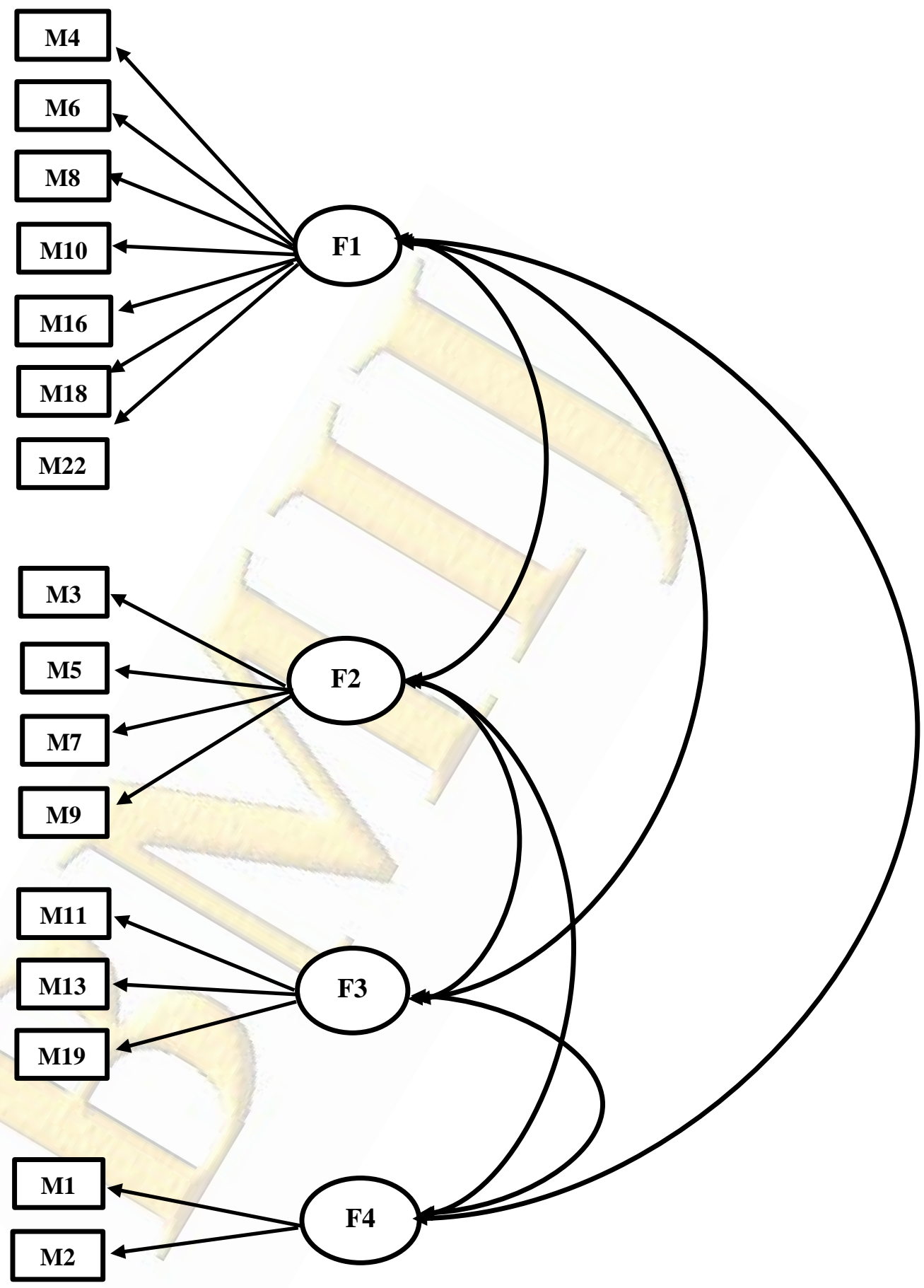

Figure 1. Confirmatory Factor Analysis Concerning the Scale Findings for the Attitudes of Customers towards Purchasing Tendency within the context of Business, Marketing and Sales Officers' Genders 
Findings related to exploratory factor analysis conducted to determine the reliability of Scale for the Attitudes of Customers towards Purchasing Tendency within the context of Business, Marketing and Sales Officers' Genders are shown in Table 5.

Table 5. Goodness Fit Index of the Model-Based on the Scale for the Attitudes of Customers towards Purchasing Tendency within the context of Business, Marketing and Sales Officers' Genders

\begin{tabular}{lccc}
\hline Fit Measure & Good Fit & Acceptable Fit & Recommended Model \\
\hline RMSEA & $0<$ RMSEA $<0,05$ & $0,05<$ RMSEA $<0,10$ & 0,050 \\
NFI & $0,95 \leq \mathrm{NFI} \leq 1$ & $0,90 \leq \mathrm{NFI} \leq 0,95$ & 0,966 \\
CFI & $0,97 \leq \mathrm{CFI} \leq 1$ & $0,95 \leq \mathrm{CFI} \leq 0,97$ & 0,98 \\
GFI & $0,95 \leq \mathrm{GFI} \leq 1$ & $0,90 \leq \mathrm{GFI} \leq 0,95$ & 0,964 \\
AGFI & $0,90 \leq \mathrm{AGFI} \leq 1$ & $0,85 \leq \mathrm{AGFI} \leq 0,9$ & 0,928 \\
\hline $\mathbf{x} \mathbf{2} / \mathbf{d f}$ & $\mathbf{0}<\mathbf{x} \mathbf{2} \mathbf{d f}<\mathbf{3}$ & $\mathbf{1 5 3 , 6 1 6 / 6 8 = 2 , 2 5 9}$ \\
\hline \multicolumn{4}{c}{}
\end{tabular}

The value that tests statistical suitability of the model and the sample analysed in the confirmatory factor analysis is the $x^{2}$ value (Schumacher \& Lomax, 2004). The $x^{2}$ value tests whether the covariance matrix of the population is equal to the covariance matrix applied to the model. However, since this value is sensitive to sampling size and $x^{2}$ value will be high in samplings with high numbers, it is considered more appropriate to use $\mathrm{x}^{2} / \mathrm{df}$ value corrected with a degree of freedom (df) (Bagozzi, 1981: 377). The $x^{2} /$ df value obtained in the study was found to be 2.259 . This result indicates that the model is statistically significant. Besides, it is pointed out that the IFI value, which takes into account both the sampling size and the complexity in the model, was found .998, is considered at good fit when it is .95 or above (Şimşek, 2007: 212). The IFI value, The IFI value in this research, which is not included in table 5, was found to be .998, which indicates a good fit.

Chi-square $\left(\mathrm{x}^{2}\right)$ Fit Goodness Test and RMSEA, CFI, GFI and NFI values were calculated for evaluating the suitability of the model, and RMSEA, CFI, GFI, AGFI and NFI values were found at the excellent fit level according to the goodness fit index of the model. This indicates that the factors of the Scale for the Attitudes of Customers towards Purchasing Tendency within the context of Business, Marketing and Sales Officers' Genders, which were determined with the exploratory factor analysis, are 
also confirmed and supported as an evaluation result of the confirmatory factor analysis performed.

\section{CONCLUSION, DISCUSSION AND RECOMMENDATIONS}

The research is prepared to develop a valid and reliable scale that will allow examining the perceptions of customers towards purchasing tendency within the context of business, marketing and sales officers' genders. The exploratory factor and confirmatory factor analysis and reliability studies conducted in the study were carried out with the data obtained from face-to-face questionnaires conducted with 511 consumers who were selected through judgemental sampling method from the corporate (brand) business stores in the city centre of Niğde. The study group of the research consists of 511 people who shopped from ten national and international brand stores between 01 and 31 December 2019.

The Scale for the Attitudes of Customers towards Purchasing Tendency within the context of Business, Marketing and Sales Officers' Genders was found valid and reliable after the exploratory and confirmatory factor analyses. Considering this result, the scale is thought to be appropriate for use in corporate or branded stores both in Turkey and around the world.

The study was limited to 511 consumers shopping from national and international branded business stores in the city centre of Niğde between 01 and 31 December 2019. In further studies, The Scale for the Attitudes of Customers towards Purchasing Tendency within the context of Business, Marketing and Sales Officers' Genders may be applied in different regions or cities, and the issue can be examined theoretically and practically with different samplings. In addition to meeting the public's need for information and contributing to the literature, the research findings are thought to be useful in developing business marketing planning and strategies, especially for marketing and sales managers. 


\section{REFERENCES}

Akdoğan, Ş. \& Karaarslan, M. H. (2010). Mağaza İçerisinde Tüketicinin Kararını Yönlendiren Kişilerin Etkisinin Senaryo Yöntemi ile Ölçülmesi. Tüketici ve Tüketim Araştırmaları Dergisi, 2(2), pp. 29-48, from https://s3.amazonaws.com/academia.edu.documents/31069746/cilt-2-sayi-2-2010. (access: 16.04.2020).

Arnold, K. A. \& Bianchi, C. (2001). Relationship Marketing, Gender, and Culture: Implications For Consumer Behavior. ACR North American Advances. https://doi.org/10.1080/0959396042000178179.

Arnould, E., J., Price, L. \& ZINNKHAN, G. M. (2002). Consumers. McGraw-Hill/Irwin, NewYork, USA.

Avery, J. (2012). Defending The Markers of Masculinity: Consumer Resistance to Brand GenderBending, International Journal of Research in Marketing, 29(4), pp. 322-336. https://doi.org/10.1016/j.ijresmar.2012.04.005.

Bagozzi, Richard, P. (1981). Evaluating Structural Equation Models with Unobservable Variables and Measurement Error: A Comment, Journal of Marketing Research, 18(3), pp. 375-381. https://doi.org/10.1177/002224378101800312.

Bakshi, S. (2012). Impact of Gender on Consumer Purchase Behaviour, Journal of Research in Commerce and Management, 1(9), 1-8. available at: http://www.abhinavjournal.com/images/Commerce_\&_Management/Sep12/1.pdf (access: 16.04.2020).

Barletta, M. (2003). Marketing to Women: How to Understand, Reach, and Increase Your Share of The World's Largest Market Segment, Chicago: Dearborn Trade Publishing. from https://books.google.com.tr/books?hl=tr\&lr=\&id=3il58OdP1mUC\&oi (access: 16.04.2020).

Büyüköztürk, Ş. (2010). Sosyal Bilimler İçin Veri Analizi El Kitabı. Ankara: Pegem Yayıncılık. ISBN 978975-6802-74-8, DOI 10.14527/9789756802748.

Büyüköztürk, Ş. (2019). Sosyal Bilimler için Veri Analizi El Kitabı İstatistik, Araştırma Deseni SPSS Uygulamaları ve Yorum, Pegem Akademi Yayıncllk, pp. 001-214, Ankara. ISBN 978-975-6802-74-8, DOI $10.14527 / 9789756802748$.

Creswell, J. W. (2014). Research Design: Qualitative, Quantitative and Mixed Methods Approaches (4th Ed.). Thousand Oaks, CA: Sage Publications.

Çabuk, S. \& Araç, S., K. (2013). Psikografik Bir Pazar Bölümlendirme Değişkeni Olarak Cinsiyet Kimliği: Tüketim Araştırmalarında Cinsiyet Kimliği Kavramının İncelenmesi. Çukurova Üniversitesi Sosyal Bilimler Enstitüsü Dergisi, 22(2), 27-40. https://dergipark.org.tr/en/pub/cusosbil/issue/4393/60444 (access: 16.04.2020).

Dökmen, Z., Y. (2015). Toplumsal Cinsiyet: Sosyal Psikolojik Açılamalar, İstanbul: Remzi Kitapevi.

Ersoy, E. (2009). Cinsiyet Kültürü İçerisinde Kadın ve Erkek Kimliği (Malatya Örneği), Fırat Üniversitesi Sosyal Bilimler Dergisi, 19(2), 209-230. available at: http://web.firat.edu.tr/sosyalbil/dergi/arsiv/cilt19/sayi2/209-230.pdf (access: 16.04.2020).

Field, A. (2009). Discovering Statistics Using SPSS. Sage Publications.

Fischer, E. \& Arnold, S., C. (1990). More Than A Labor of Love: Gender Role and Christmas Gift Shopping, Journal of Consumer Research, 17: 333-345. https://doi.org/10.1086/208561. 
Kalaycı, Ş. (2010). SPSS Uygulamalı Çok Değişkenli İstatistik Teknikleri, (Vol. 5). Ankara, Turkey: Asil Yayın Dağıtım.

Karahan, F., D. (2018). İlmi Etüdler Derneği ve Burdur Mehmet Akif Ersoy Üniversitesi 7. Türkiye Lisansüstü Çalı̧̧malar Kongresi, Burdur, pp. 169-186. from https://www.ilem.org.tr/mediaf/1._cilt.pdf (access: 16.04.2020).

Karahan, F. D. \& Adak, N. (2019). Tüketimin Cinsiyeti: Tüketim Toplumunda Gençlerin Tüketim Eğilimleri, Akdeniz Kadın Çalışmaları ve Toplumsal Cinsiyet Dergisi, 2(1), pp. 118-148. DOI:10.33708/ktc.560758.

Karasar, N. (2019). Bilimsel Araştırma Yöntemi, Nobel Akademi, Ankara.

Kılıçer, T., Boyraz, E. \& Tüzemen, A. (2016). Kadın, Erkek, Ya Da? Hediye Satın Alma Davranışında Cinsiyet Kimliği Rolünün Etkisi. Ege Academic Review, 16(1), 121-133. available at: https://pdfs.semanticscholar.org/bc22/bfa540d4b898d15d77dc896f5a0c37c0e2cc.pdf $\quad$ (access: 16.04.2020).

Lieven, T. (2016). Customers Choice of a Salesperson During The İnitial Sales Encounter. Journal of Retailing and Consumer Services, 32, 109-116. https:// doi.org/10.1016/j.jretconser.2016.06.005.

Ndubisi, N. O. (2006). Effect of Gender on Customer Loyalty: A Relationship Marketing Approach. Marketing İntelligence \& Planning. DOI 10.1108/02634500610641552.

Özdamar, K. (2002). Paket Programlar ile İstatiksel Veri Analizi, Kaan Kitabevi, Eskişehir.

Peterson, R., A. (2005). Response Construction in Consumer Behavior Research, Journal of Business Research, 58, ss.348-353. https://doi.org/10.1016/S0148-2963(03)00100-0.

Schermelleh-Engel, Karin; Helfried Moosbrugger \& Hans Müler, (2003). Evaluating the Fit of Structural Equation Models: Tests of Significance and Descriptive Goodness-of-Fit Measures, Methods of Psychological Research Online, 8(2), pp. 23-74. available at: http://citeseerx.ist.psu.edu/ viewdoc/download?doi=10.1.1.509.4258\&rep=rep1\&type=pdf (access: 16.04.2020).

Schumacher, R. E. \& Lomax, R. G. (2004). A Beginner's Guide to Structural Equation Modeling. Mahwah, New Jersey: Lawrence Erlbaum Associates. https://doi.org/10.4324/9780203851319.

Strouse, A., W. (2019). Gender Trouble Couplets, Volume 1. DOI:10.21983/P3.0266.1.00.

Şimşek, Ö. F. (2007). Yapısal Eşitlik Modellemesine Giriş, Temel İlkeler ve LíSREL Uygulamaları, Ekinoks Yayınları, Ankara.

Tabachnick, B. G., Fidell, L. S. \& Ullman, J. B. (2007). Using Multivariate Statistics (Vol. 5). Boston, MA: Pearson. available at: https://www.pearsonhighered.com/ assets/preface/0/1/3/4/0134790545.pdf (access: 16.04.2020).

Tekvar, S., O. (2016). Tüketici Davranışlarının Demografik Özelliklere Göre Tanımlanması, İnsan ve Toplum Bilimleri Araştırmaları Dergisi, 5(6), 1601-1616. https://doi.org/10.15869/itobiad.256244.

Yurdugül, H. (2005). Ölçek Geliştirme Çalışmalarında Kapsam Geçerliği İçin Kapsam Geçerlik İndekslerinin Kullanılması, XIV. Ulusal Eğitim Bilimleri Kongresi (Kongre Kitabı), Pamukkale Üniversitesi Eğitim $\quad$ Fakültesi. Denizli. 28-30 Eylül. from http://yunus.hacettepe.edu.tr/ yurdugul/3/indir/PamukkaleBildiri.pdf (access: 16.04.2020). 